\title{
Strategic Information System Planning: Information Systems Required in Vocational School Models
}

\author{
Widia Murni Wijaya \\ Educational Administration, School of Postgraduate \\ Universitas Pendidikan Indonesia \\ Bandung, Indonesia \\ widiamw@student.upi.edu
}

\begin{abstract}
The main purpose of this study was to meet the need for the provision of information systems in vocational school models quickly and structured, to answer some problems that using the needs of information systems identified, and can be a guide in the development or improvement of strategic information system planning in other institutions. The case study of this study conducted in vocational school models in Palembang city, South Sumatra, Indonesia. Analysis tools used in this study are Political, Economic, Social and Technology (PEST), and Critical Success Factor (CSF). Framework models used is Ward and Peppard models, and using McFarlan Grid portfolio. Information systems that found in the vocational school models, seen from McFarlan Grid Portfolio are still a part of Key Operational and Support. Whereas part of the Strategic and High Potential is essential for the advancement of ICT today, the school should have followed the trend of technology to develop information systems in schools to be more effective. These findings have implications on school management information systems and ICT part of the school to develop information systems on the important activities in the school.
\end{abstract}

Keyword - Strategic Information System Planning, Vocational School, Ward and Peppard Models.

\section{INTRODUCTION}

Strategic planning showing a comprehensive analysis, systematically to develop a plan of action/activity [1]. Information system (IS) is a tool for individual and organization in use technology to collect, process, save, utilize and disseminate information manually change activities into an integrated operational system [2] [3]. Strategic information system planning (SISP) is a set of long term goal that describes the system requirement and architecture of information technology (IT) to achieve organizational goal [4]. In outline, SISP identify the objectives and determine strategies for educational organization as Vocational School. Vocational school is part of the national education system that has an important role in preparing human resources that ready to work independently or work in the industrial sector.

The problem is the use of resource that based on IS is still less support, some activities are still semi-manually, seeing that the vvocational school models, in this case is Vocational school No. 2 Palembang that based on technology should have implemented an IS/IT on important activities so that this problem need to be solved using SISP. SISP will be developed through the phase of analysis to solution of the best strategy to be implemented by the company for the long term so that the company will have a reference in achieving the vision and mission [5] [6]. SISP is the process whereby an organization determines the portfolio of computer application to manage information in order to achieve the business goal [7] [8] [9]. This methodology develops the idea of harmony between strategic business planning and IS planning. It is emphasize that the implementation of IS should be direct transformation of the organization strategy that takes into the mission, goal, objective, strategy and critical success factor [10] [11]. The identification of problems described in Table. 1

Table 1. Identification of Problem

\begin{tabular}{|c|l|l|}
\hline No & Problem & Solution \\
\hline 1 & IS less support & IS development \\
\hline 2 & $\begin{array}{l}\text { IS infrastructure less } \\
\text { support }\end{array}$ & IS Infrastructure development \\
\hline 3 & There is no analysis system & Manufacture of analysis system \\
\hline 4 & There is no IS design & Manufacture of IS design \\
\hline 5 & $\begin{array}{l}\text { Human resource ability } \\
\text { less support }\end{array}$ & Human resource training \\
\hline
\end{tabular}

The table 1 shown that there are five problems that exist in the vocational school models related to the IS, thus included the solution to resolve the problems identified.

\section{METHODOLOGY}

The research methodology is a system or a way obtained to obtain an information/resource materials a scientific knowledge with the aim to find thing or principles that could be considered new or how to solve a problem [12]. The flowchart of research method described in Fig. 1. 


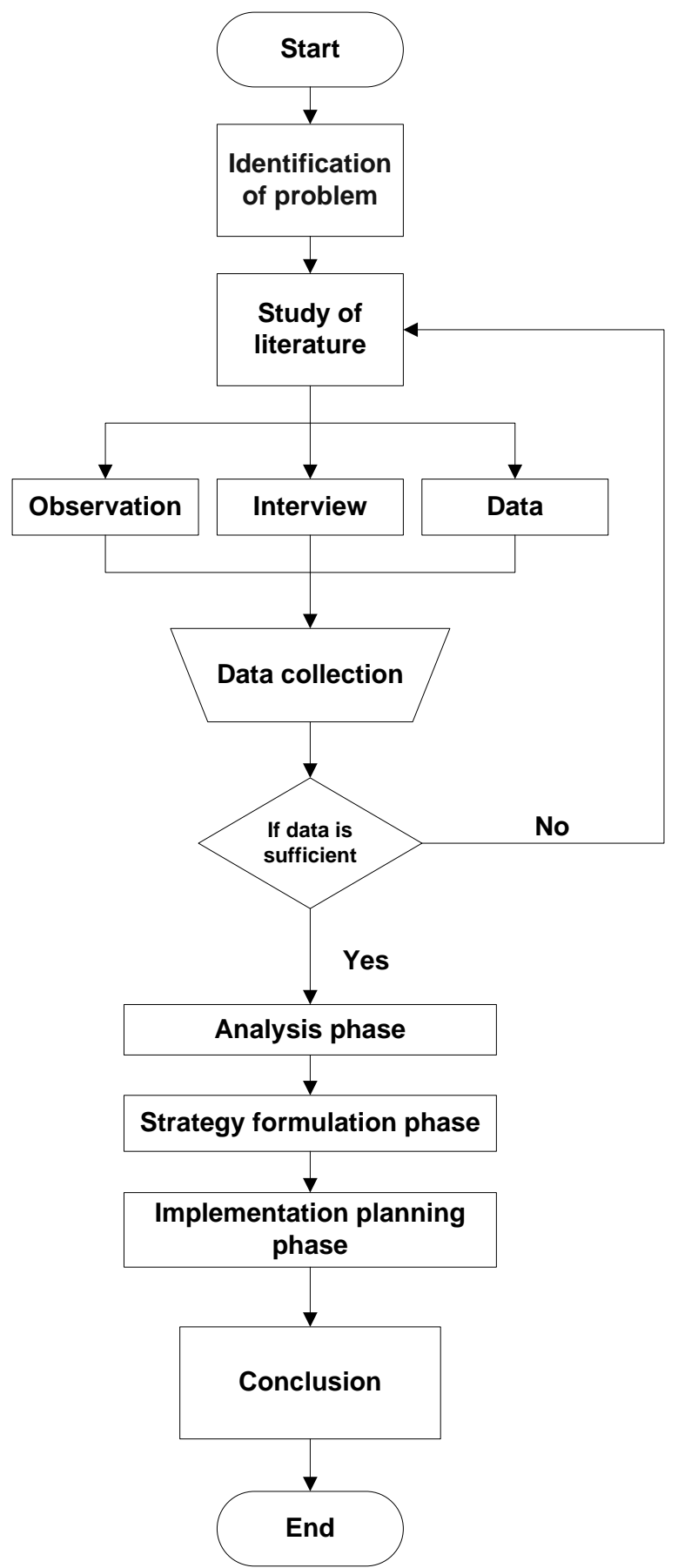

Figure 1. Flowchart of Research Methods

The methodology in this study starts from identification the problems and then continued to the study of literature, after that conduct the observations, interviews and collecting documents related to IS on vocational school models. If the data obtained is sufficient, it will proceed to the analysis phase, strategy formulation phase and implementation planning phase, but if the data is not sufficient then the research process back to the study of literature that shown on Fig. 1.
This research focused on vocational school and SISP at vocational educational institution so that the discussion regarding the implementation of IS associated with vocational school with reference to the perspective of business models and strategies for school [13]. IS strategy is explain the use of the information or the processing of information and communication to support and achieve new business strategies or competitive advantage [14]. The business strategy is the way how to position your business now by analyzing the internal and external environment as well as IS, define objectives, formulate how to achieve these goals and review them periodically [15] [16] [17].

The phase of analysis, analysis tools used are Political, Economic, Social and Technology (PEST) and Critical Success Factor (CSF) and using McFarlan Grid Portfolio. Framework models of SISP used in this research is a framework model of Ward and Peppard that described in Fig. 2.

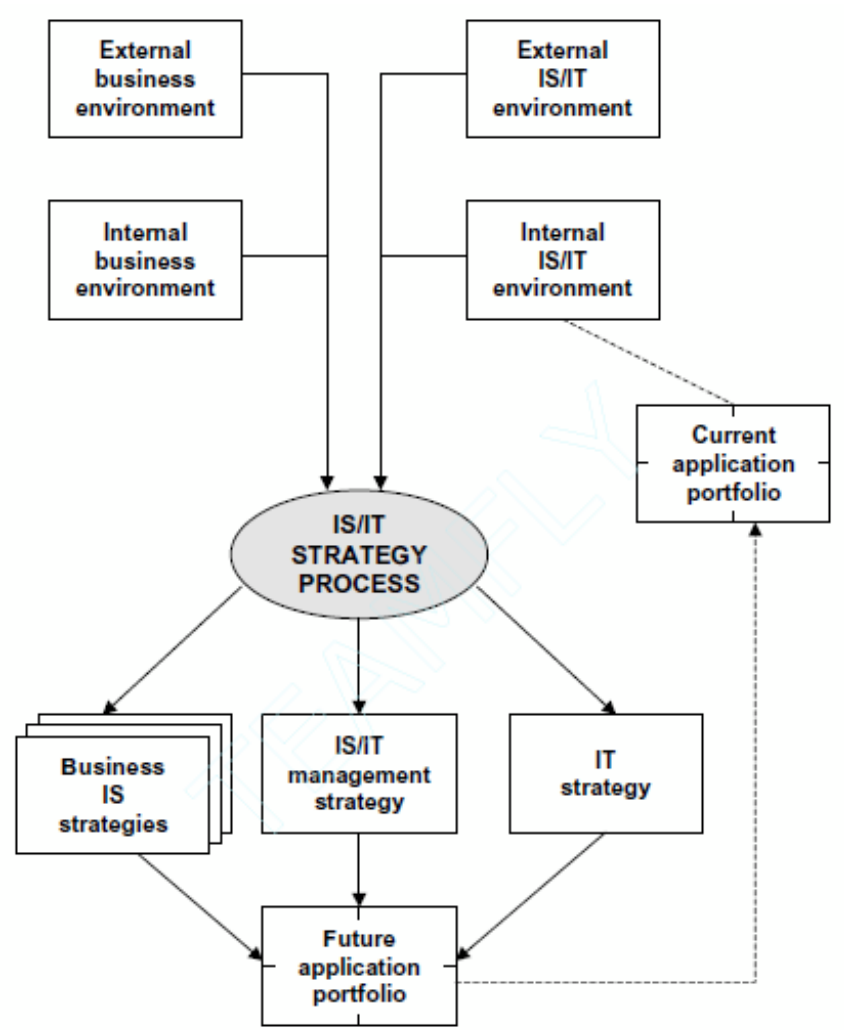

Figure 2. Framework Models of Ward and Peppard

Figure 2 describes about the input of strategic information system planning framework models of Ward and Peppard is composed of the external and internal business environment, and the external and internal IS/IT environment. In IS/IT strategy process, process whereby information and environmental analysis that obtained will be processed to produce output, including business IS strategy, IS/IT management strategy and IT strategy. Future Application Portfolio explaining about the proposed application that will be used in the nearest future. Whereas 
Current Application Portfolio describes detail about IS application that currently running by looking at the advantages and strengths in the application.

\section{RESULT AND DISCUSSION}

\section{A. Analysis of Organization Environment}

Analysis of Organization Environment conducted on the condition of internal and external organization to obtain the clear data. The analysis also conducted on the condition of IS.

1) Analysis of External Organization Environment

Analysis of external organization environment, the tools used is PEST. PEST analysis related to the influence of political, economic, social and technology that describe on table 2 .

\begin{tabular}{|c|c|c|}
\hline \multicolumn{2}{|l|}{ PEST Factor } & Requirement \\
\hline Political & $\begin{array}{l}\text { Government policies } \\
\text { for school accreditation } \\
\text { - The system of school } \\
\text { finance } \\
\text { - } \quad \text { Quality assurance } \\
\text { system of school }\end{array}$ & $\begin{array}{l}\text { IS reporting system } \\
\text { related to operating } \\
\text { licenses, financial and } \\
\text { academic quality } \\
\text { assurance of school }\end{array}$ \\
\hline Economic & $\begin{array}{ll}\text { - } & \text { School location } \\
\text { - } & \text { Aid fund/scholarship } \\
\text { - } & \text { Job fairs }\end{array}$ & $\begin{array}{l}\text { IS to display } \\
\text { information related to } \\
\text { the condition of } \\
\text { school, scholarships } \\
\text { and job vacancy }\end{array}$ \\
\hline Social & 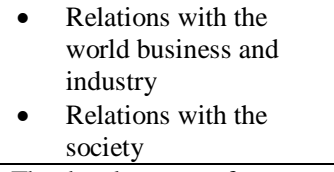 & $\begin{array}{l}\text { IS to provide } \\
\text { information related to } \\
\text { the world business } \\
\text { and industry and } \\
\text { society }\end{array}$ \\
\hline Technology & $\begin{array}{l}\text { The development of } \\
\text { Information and } \\
\text { Communication Technology } \\
\text { (ICT) }\end{array}$ & $\begin{array}{l}\text { Providing the } \\
\text { adequate } \\
\text { infrastructure }\end{array}$ \\
\hline
\end{tabular}

2) Analysis of External IS Environment

Analysis of External IS Environment conducted to determine the trend of today's technology and the advantage that describe on table 3 .

Table 3. Analysis of External IS Environment

\begin{tabular}{|l|l|}
\hline Trend of Technology & Advantage \\
\hline $\begin{array}{l}\text { Computer hardware } \\
\text { specification that the } \\
\text { performance is more faster }\end{array}$ & $\begin{array}{l}\text { Ease the work to become more } \\
\text { effective and efficient }\end{array}$ \\
\hline $\begin{array}{l}\text { Application that based on } \\
\text { Graphical User Interface (GUI) }\end{array}$ & Ease the user to use the application \\
\hline $\begin{array}{l}\text { Desktop Application, Web- } \\
\text { Based Service }\end{array}$ & $\begin{array}{l}\text { Ease the management and delivery } \\
\text { of information }\end{array}$ \\
\hline Open-Source Database & Reduce the cost of data management \\
\hline
\end{tabular}

3) Analysis of Internal Organization Environment

Analysis of Internal Organization Environment, tools used is CSF. CSF is used to determine in more detail the organization strategic that researched so that the needs of the organization are knowable.

\section{Vision and Mission of School}
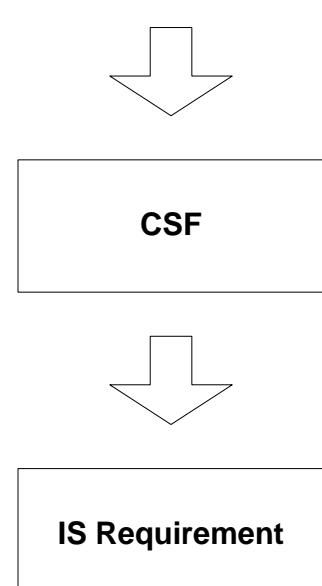

Figure 3. CSF

Description of figure 3 will be shown in table 4 about analysis of internal organization environment using CSF.

Table 4. Analysis of External IS Environment

\begin{tabular}{|l|l|l|}
\hline Vision and Mission & CSF & IS Requirement \\
\hline $\begin{array}{l}\text { The center of education } \\
\text { and vocational level } \\
\text { technology training and } \\
\text { able to compete in the } \\
\text { global era }\end{array}$ & $\begin{array}{l}\text { Provide the } \\
\text { infrastructure to } \\
\text { meet the standards }\end{array}$ & - \\
\hline $\begin{array}{l}\text { Realize the information } \\
\text { center and the publication } \\
\text { of learning model based } \\
\text { on IT }\end{array}$ & $\begin{array}{l}\text { Manufacture of } \\
\text { facilities and } \\
\text { infrastructure } \\
\text { based on IT }\end{array}$ & $\bullet \quad \begin{array}{l}\text { IS for } \\
\text { recapitulation of } \\
\text { student scores } \\
\text { IS for employee } \\
\text { attendance } \\
\text { IS for schedule } \\
\text { of subjects }\end{array}$ \\
\hline $\begin{array}{l}\text { Increase cooperation dual } \\
\text { system of education with } \\
\text { the world business and } \\
\text { industry that national, } \\
\text { regional and international } \\
\text { scale }\end{array}$ & $\begin{array}{l}\text { Strengthening of } \\
\text { cooperation }\end{array}$ & - \\
\hline $\begin{array}{l}\text { Realizing the graduates to } \\
\text { be able to communicate } \\
\text { globally and be able to } \\
\text { compete at the national, } \\
\text { regional and international }\end{array}$ & $\begin{array}{l}\text { Training and } \\
\text { practice } \\
\text { communicating } \\
\text { with a global } \\
\text { language }\end{array}$ & - \\
\hline
\end{tabular}

4) Analysis of Internal IS Environment

Analysis of internal IS environment was conducted to determine the condition of the IS current school encompasses applications that used and the IT infrastructure using McFarlan Grid portfolio that shown on tabel 5.

Table 5. Analysis of Internal IS Environment

\begin{tabular}{|l|l|}
\hline Strategic & $\underline{\text { High Potential }}$ \\
\hline - IS New Student Registration & - \\
\hline$\underline{\text { Key Operational }}$ & - Official Web \\
\hline
\end{tabular}


B. IS Identification of Solution

IS Identification of Solution based on the analysis of internal and external organization environment and IS environment that shown on table 6 .

Table 6. Application Portfolio

\begin{tabular}{|l|l|}
\hline Strategic & High Potential \\
- IS Management School & - IS Industry Work Practice \\
- IS Schedule of Subjects & \\
\hline $\begin{array}{l}\text { - IS Recapitulation of Student Scores } \\
\text { - IS New Student Registration }\end{array}$ & - IS Employee Attendance \\
Key Operational & - Official Web \\
\hline
\end{tabular}

C. Formulation of Strategy

After conducting the analysis on the internal and external environment, it can be formulated IS strategy as follows.
1) Improve the teaching and learning process of the school based on IS.

2) Provide the access of information to all citizens in school.

3) Improve the human resource ability in school.

4) Provide the access of information to the world business and industry, and society.

5) Develop the infrastructure of the school

\section{Implementation Planning}

The last phase in this research is the implementation planning of the IS strategy and application portfolio that identified. The following table 7 shown the implementation planning of IS strategy and table 8 shown the implementation planning of application.

Table 7. Implementation Planning of IS Strategy

\begin{tabular}{|c|c|c|c|c|c|c|}
\hline \multirow{2}{*}{ Program (IS Strategy) } & \multirow{2}{*}{ Indicator } & \multicolumn{5}{|c|}{ Year } \\
\hline & & 2017 & 2018 & 2019 & 2020 & 2021 \\
\hline $\begin{array}{l}\text { Improve the teaching and } \\
\text { learning process of the school } \\
\text { based on IS }\end{array}$ & $\begin{array}{l}\text { Develop the IS } \\
\text { application }\end{array}$ & $\mathrm{V}$ & $\mathrm{V}$ & - & - & - \\
\hline $\begin{array}{l}\text { Provide the access of } \\
\text { information to all citizen in } \\
\text { school }\end{array}$ & $\begin{array}{l}\text { Utilize the information } \\
\text { portal of the school } \\
\text { (official web and wall } \\
\text { magazine) }\end{array}$ & $\mathrm{V}$ & $\mathrm{V}$ & V & $\mathrm{V}$ & $\mathrm{V}$ \\
\hline $\begin{array}{l}\text { Improve the human resource } \\
\text { ability in school }\end{array}$ & $\begin{array}{l}\text { Held a workshop for } \\
\text { teachers and employees }\end{array}$ & $\mathrm{V}$ & V & V & $\mathrm{V}$ & $\mathrm{V}$ \\
\hline $\begin{array}{l}\text { Provide the access of } \\
\text { information to the world } \\
\text { business and industry and } \\
\text { society }\end{array}$ & $\begin{array}{l}\text { Develop the IS } \\
\text { applications }\end{array}$ & V & - & - & - & - \\
\hline $\begin{array}{l}\text { Develop the infrastructure of the } \\
\text { school }\end{array}$ & $\begin{array}{l}\text { Improve the school } \\
\text { infrastructure }\end{array}$ & V & V & - & - & - \\
\hline
\end{tabular}

Table 8. Implementation Planning of Application

\begin{tabular}{|l|c|c|c|c|c|}
\hline \multirow{2}{*}{ Program (Application) } & \multicolumn{5}{|c|}{ Year } \\
\cline { 2 - 6 } & $\mathbf{2 0 1 7}$ & $\mathbf{2 0 1 8}$ & $\mathbf{2 0 1 9}$ & $\mathbf{2 0 2 0}$ & $\mathbf{2 0 2 1}$ \\
\hline IS Management School & $\mathrm{V}$ & - & - & - & - \\
\hline IS Schedule of Subjects & - & $\mathrm{V}$ & - & - & - \\
\hline $\begin{array}{l}\text { IS Recapitulation of } \\
\text { Student Scores }\end{array}$ & $\mathrm{V}$ & - & - & - & - \\
\hline IS Industry Work Practice & $\mathrm{V}$ & - & - & - & - \\
\hline IS Employee Attendance & - & $\mathrm{V}$ & - & - & - \\
\hline
\end{tabular}

\section{CONCLUSION}

From the results, it could be concluded that the vocational school models need to implement an IS/IT on important activities using SISP because it can improve the teaching and learning process of the school based on IS, provide the access of information to all citizen in school, improve the human resource ability in school and provide the access of information to the world business and industry, and society. By analyzing the internal and external environment of the organization and IS/IT, it will be known the needs of the IS/IT that required in school to improve the school performance.

\section{REFERENCES}

[1] Ward, John and Peppard, Strategic Planning for Information Systems. UK: Wiley, 2002.

[2] Bhatnagar, A, "Strategic Information Systems Planning: Alignment of IS/IT Planning and Business Planning", 2006, unpublished.
[3] O'Brien, J, Pengantar Sistem Informasi: Perspektif Bisnis dan Manajerial Edisi Bahasa Indonesia. Jakarta: Salemba Empat, 2005.

[4] Turban, E., Rainer, R. K., and Potter, R. E, Introduction to Information Technology. USA: Wiley, 2003.

[5] Ghasemi, M., V. Shafeiepour, M. Aslani and E. Barvayeh, "The impact of Information Technology (IT) on modern accounting systems", Proc. Soc. Behav. Sci., 28: 112-116. DOI: 10.1016/j.sbspro.2011.11.023, 2011, in press.

[6] Grembergen, W.V. and Saull, R, "Aligning business and information technology through the balanced scorecard at a major Canadian financial group: Its status measured with an IT BSC maturity model", Proceedings of the 34th Annual Hawaii International Conference on System Sciences, Jan. 3-6, IEEE Xplore Press. DOI: 10.1109/HICSS.2001.927176, 2001, in press.

[7] Mohdzain, M. B., and Ward, J. M., "A study of subsidiaries' views of information systems strategic planning in multinational organizations", Journal of Strategic Information Systems, 2007, 16, pp. 324-352, in press.

[8] Newkirk, H. E., and Lederer, A L, "The effectiveness of strategic information systems planning under environmental uncertainty", Information \& Management, 2006, 43, pp. 481-501, in press. 
[9] Basu, V., Hartono, E., Lederer, A.L., and Sethi, V. "The impact of organizational commitment, senior management involvement, and team involvement on strategic information systems planning", Information \& Management, 2002, 39, pp. 513-524, in press.

[10] Kearns, G.S, "The effect of top management support of SISP on strategic IS management: insights from the US electric power industry", The international Journal of Management Science, 2006, 34 , pp. $236-253$, in press.

[11] Pant, S., Taek H., and Hsu, Ch., A, "Framework for developing Web information systems plans: illustration with Samsung Heavy Industries Co. Ltd", Information \& Management, 2001, 38, pp. 385408 , in press.

[12] Kountur, Rony, Metode Penelitian. Jakarta: PPM, 2007.

[13] Applegate, L. M., Austin. R. D., and Soule. D. L, Corporate Information Strategy and Management: Text And Cases. United States: MCGraw-HiJL/Irwin, a business unit of the McGraw-Hili Companies, Inc, 2009.

[14] Hesterly, W. S., and Barney, J, Strategic Management and Competitive Advantage: Concepts and Cases 3rd ed. Pearson Prentice Hall, 2009.

[15] Craig, J. C., and Grant, R. M, Manajemen Strategik. Jakarta: Mediator, 2008.

[16] Gartlan, J., and Shanks, G, "The Alignment of Business and Information Technology Strategy in Australia", Australasian Journal of Information Systems, 2007, Vol 14 No.2, in press.

[17] Bateman, T. S, Management: Building Competitive Advantage. New York: Business Week Edition, 2001 